\title{
Experience of treatment of lung cancer patients using paclitaxel and carboplatin
}

Anwar Jusuf *, Sutji Astuti Mariono**, Karmel L. Tambunan*, A. Harryanto Reksodiputro*, Noorwati

Soetandyo*, Ronald Hukom*, Eddy Suratman*, A. Mulawarman Jayusman*

\begin{abstract}
Abstrak
Sembilan belas pasien kanker paru jenis karsinoma bukan set kecil stage Jll \& JV mendapat kemoterapi dengan paduan paklitaksel dan karboplatin di Rumah Sakit Kanker Dharmais dan Rumah Sakit Pusat Pertamina Jakarta, terdiri dari J4 laki-laki dan 5 perempuan. Diagnosis histologis ialah adenokarsinoma pada 13 pasien, karsinoma skuamosa pada 4 pasien dan karsinoma adenoskuamosa pada J pasien. Empat belas pasien termasuk stage JV, stage llJB terlihat pada 4 pasien dan stage 11/A pada 1 pasien. Paduan obat terdiri dari paklitaksel, dengan dosis 135-200 mg/m2 dan karboplatin $300 \mathrm{mg} / \mathrm{m} 2$ atau AUC $6 \mathrm{mg} / \mathrm{ml} . \mathrm{min}$, diberikan melalui infus setiap 3 minggu, paling sedikit 3 siklus. Pasien diikuti secara teratur sampai meninggal. Respon objektif berupa respon parsial (partial response) terlihat pada 12 pasien (63\%), 2 pasien tidak menunjukkan perubahan (stable disease) dan perburukan terlihat pada 5 orang (26\%). Dua pasien masih hidup masing-masing 22 dan 23 bulan setelah kemoterapi dimulai. Masa tahan hidup 1 tahun adalah 58\% dan masa tengah tahan hidup ialah 14 bulan.
\end{abstract}

\begin{abstract}
Nineteen patients with stage 111 \& IV nonsmall cell lung cancer were treated with regimen containing paclitaxel and carboplatin at Dharmais National Cancer Center Hospital and Pertamina General Hospital, Jakarta - Indonesia. There were 14 males and 5 females, the histologic diagnosis being adenocarcinoma in 13 patients, squamous carcinoma in 5 patients and adenosquamous carcinoma in $J$ patient. Fourteen patients were in stage IV, 4 had stage 11/B, one had stage fl/A disease. The regimen contains paclitaxel 135-200 mg/m2, combined with carboplatin $300 \mathrm{mg} / \mathrm{m} 2$ or AUC $6 \mathrm{mg} / \mathrm{ml}$. min, given every 3 weeks. Those who undenvent at least 3 cycles of chemotherapy were followed up until death. Objective improvement (partial response) was seen in 12 patients or 63\%; 2 had stable disease (11\%) and 5 had progressive disease (26\%). Two patients are still alive at 22 months and 23 months after starting chemotherapy. The one year survival rate was 58\% and median survival time was 14 months.
\end{abstract}

Keywords: nonsmall cell carcinoma, chemotherapy, paclitaxel, carboplatin

The treatment of lung cancer has been a problem in Indonesia. In Dharmais National Cancer Center Hospital, 541 lung cancer patients were hospitalized during 1993-1997, 344 of them were nonsmall cell lung cancer in stage III \& IV. Chemotherapy should have been indicated for them, but mainly due to financial reason only 54 of them could be so treated. In spite of such a situation, a small number of them were able to provide cytostatic drugs for themself.

Paclitaxel in combination with carboplatin were among of the regimens that were chosen for these patients. In

\footnotetext{
* Dharmais National Cancer Center Hospital, Faculty of Medicine, University of Indonesia, Jakarta, Indonesia

** Pertamina Central General Hospital, Jakarta, Indonesia
}

Pertamina Hospital, 40-50 nonsmall lung cancer patients were seen annually. The majority of the patients were the employees of Pertamina, for whom the cytostatic drugs were provided by the company.

This combination was relatively new, introduced in Jakarta in 1993, but it was not until 1994 that we began to use this combination for the treatment of lung cancer in Dharmais Hospital and since 1996 in Pertamina Hospital. According to literature .. this combination is quite effective for nonsmall cell lung cancer with tolerable side effects. To evaluate the usefulness of this combination for our patients, we studied retrospectively the outcome of treatment using this combination on lung cancer ;'atients in both hospital. 


\section{MATERIAL AND METHODS}

This is a retrospective study on nonsmall cell lung cancer patients that were treated during 1994-1998 at Dharmais National Cancer Center Hospital and Pertamina Hospital. The inclusion criterias were :

confirmed histologic diagnosis of nonsmall cell carcinoma

nonsmall normal blood counts, normal CCT

stage IIIA, IIIB and IV, with measurable disease, performance status $>/ 70$ (Kamofsky)

chemotherapy regimen, containing paclitaxel 135 $\mathrm{mg} / \mathrm{m} 2-200 \mathrm{mg} / \mathrm{m} 2$ and carboplatin $200 \mathrm{mg} / \mathrm{m} 2$ or AUC $6 \mathrm{mg} / \mathrm{ml} . \mathrm{mm}$ given every 3 - 4 weeks, for 6 cycles.

at least 3 cycles must be administered

follow up was done every month up to 3 months and then every 3-4 months or whenever the patients had complaints, until death

objective responses were be recorded, according to UICC criteria (complete response, partial response, stable disease and progressi ve disease) by physical examination and chest X-ray examination

all side effects were recorded according to WHO Classification

dates of death were recorded in the patient's journal, survival time was calculated from the date of the beginning of chemotherapy. A special call was given on December 31si, 1998 to check which patients were surviving

The details of treatment were as follows :

hydration with saline solution before the administration of cytostatic

premedication with dexamethason, ondansetron and diphenhydramine

paclitaxel was given over 3 hrs infusion, the dose being $135 \mathrm{mg} / \mathrm{m} 2$ at the beginning of the study, later being $175 \mathrm{mg} / \mathrm{m} 2$ or $200 \mathrm{mg} / \mathrm{m} 2$. $\%$ surviving carboplatin was given $300 \mathrm{mg} / \mathrm{m} 2$ intravenousl y, later dosed to a targeted AUC 6

hematologic examination (Hb, granulocytes, trombocyte count) was performed every week during treatment

\section{RESULTS}

Nineteen patients were recruited for evaluation. There were 12 males and females, the age ranged between 42 years and 73 years (median : 57 yrs). Fourteen of them were stage IV disease, 4 stage IIIB disease and one had stage IIIA disease. Histologic diagnoses were squamous carcinoma in 4 patients, adenocarcinoma in 14 patients and adenosquamous carcinoma in I patient. Seventeen patients completed 6 cycles of chemotherapy, one had only 3 cycles and one had 4 cycles. The shortest follow up period was 4 months and the longest was 35 months after the start of chemotherapy. Two patients are still alive at 22 and 23 months after the start of chemotherapy. Objective response was seen in 12 out of 19 patients $63 \%$. No patients had complete response, twel ve had partial response. Two patients (10,5\%) showed stable disease and progression was seen in 5 patients $(26,3 \%)$, as seen in Table 1.

Table I. Objective Response in 16 Lung Cancer Patients Treated with Paclitaxel \& Carboplatin $(\mathrm{n}=19)$

\begin{tabular}{lcc}
\hline Response & No & $\%$ \\
\hline - Complete response & 0 & 0 \\
- Partial response & 12 & 63 \\
- Stable disease & 2 & II \\
- Progressi ve disease & 5 & 26 \\
\hline
\end{tabular}

Eleven patients live one year after chemotherapy, giving the one year survival rate of 58 . The median survival time was 15 months as shown in Figure 1.

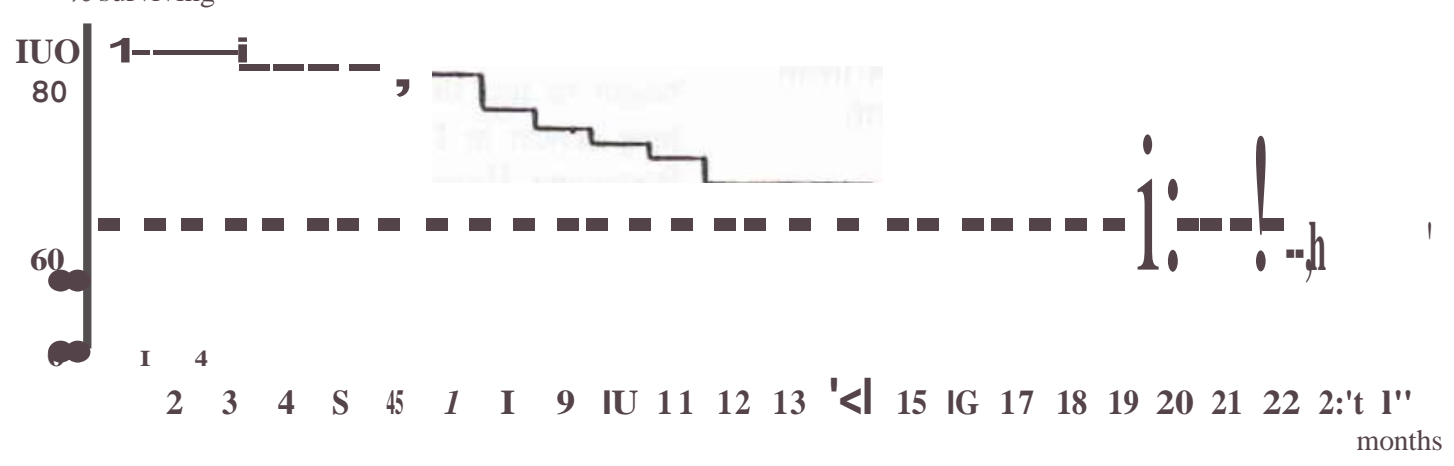
Figure J. The Survival Curve of Lung Cancer Patients Receiving a Combination of Paclitaxel and Carboplatin Calculated from the
Beginning of Chemotherapy $(n=19)$ 
Fourteen patients had stage IV disease. Among this group, 4 patients had radiotherapy for metastasis to the weight bearing bones or the primary tumor. The results are shown in Table 2 and Figure 2. Complete response was not seen, partial response in 10/14 (71\%) and progressive disease in $4 / 14$ (29\%), as seen in Table 2. Among these patients, one year survival rate was 6 out of 14 patients (43\%); the median survival time was 14 months (see Figure 2).

Table 2. Objective Response in Stage IV Disease Treated with Paclitaxel \& Carboplatin $(\mathrm{n}=14)$

\begin{tabular}{lcc}
\hline Response & No & $\%$ \\
\hline - Complete response & 0 & 0 \\
- Partial response & 10 & 71 \\
- Stable disease & & \\
- Progressive disease & 4 & 29 \\
\hline
\end{tabular}

All patients had nausea and vornitting grade 1-2, none had grade 3-4. Alopecia was seen in all patients. No renal or cardiac toxicity was found. Neurotoxicity such as peripheral neuropathy was not well recorded, but were seen in some patients, none of them had grade 3 or 4 . Serious side effects, namely grade 3 thrombocytopenia were seen in 5 patients (26\%), 1 patient (5\%) and 2 patients (11\%), respectively (Table 3).
Table 3. Side Effects of Paclitaxel \& Carboplatin Combination

\begin{tabular}{|c|c|c|}
\hline \multirow[t]{2}{*}{ Toxicity Parameter } & \multicolumn{2}{|c|}{ WHO Grade (\%) } \\
\hline & 3 & 4 \\
\hline Neutropenia & $5(31.3 \%)$ & I (6.3 \%) \\
\hline Thrombocytopeni a & 2 (12.5 \%) & \\
\hline Nausea/vomiting & & \\
\hline Neurotoxicity & & \\
\hline R'e n a 1 & & \\
\hline Cardiac & & \\
\hline
\end{tabular}

\section{DISCUSSION}

Paclitaxel and carboplatin combination has been studied by many investigators with various results, as seen in Table 4 and 5. Using similar dose of paclitaxel and carboplatin, Johnson et al, Giaccone et al and Bunn et $\mathrm{al}^{4}$ had seen response rates of less than $50 \%$ or more. Other investigators like Belani et al, Schutte et al, and Rowinsky et $\mathrm{al}^{4}$ used combinations of paclitaxel with carboplatin dosed to different targeted AUC-s, also had PR of over 50\%. Our result which was surprisingly high, may be due to more selected patients; as this is a retrospective report of patients after completing the treatment and follow up.

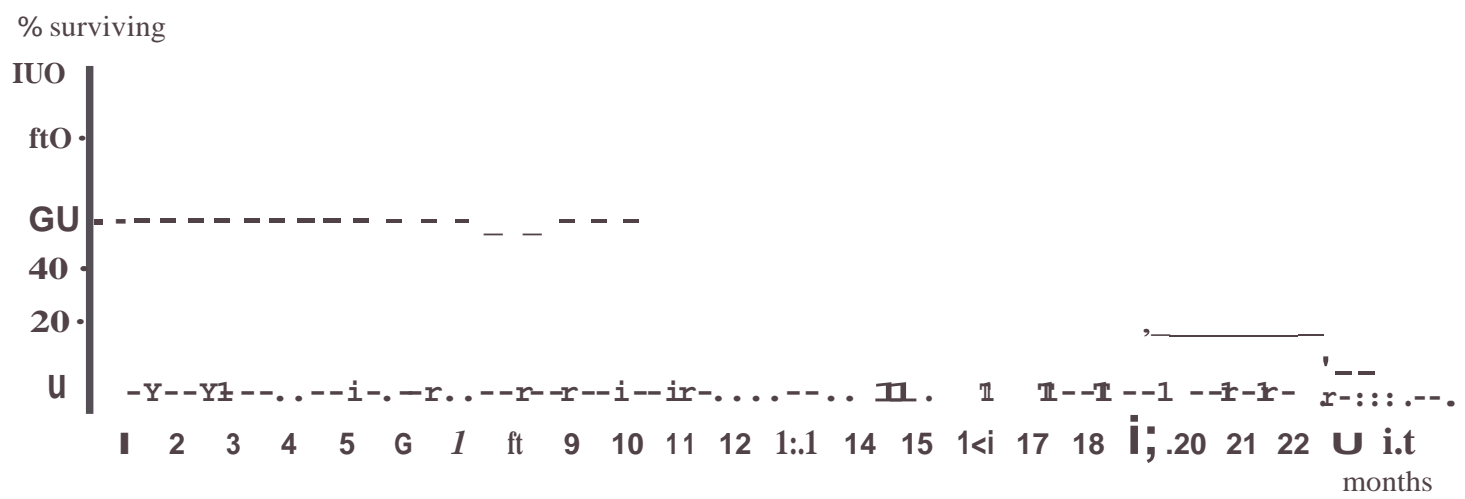

Figure 2. The Survival Curve of Patients with Stage IV Lung Cancer Receiving a Combination of Paclitaxel and Carhop/ $t^{\prime}$ Calculated after the Beginning of Chemotherapy $(n=14)$ 
Fourteen patients had stage IV disease. Among this group, 4 patients had radiotherapy for metastasis to the weight bearing bones or the primary tumor. The results are shown in Table 2 and Figure 2. Complete response was not seen, partial response in 10/14 (71\%) and progressive disease in $4 / 14$ (29\%), as seen in Table 2. Among these patients, one year survival rate was 6 ou t of 14 patients (43\%); the median survival time was 14 months (see Figure 2).

Table 2. Objective Response in Stage IV Disease Treated with Paclitaxel \& Carboplatin $(n=14)$

\begin{tabular}{lcc}
\hline Response & No & $\%$ \\
- Complete response & 0 & 0 \\
- Partial response & 10 & 71 \\
- Stable disease & & \\
- Progressive disease & 4 & 29 \\
\hline
\end{tabular}

All patients had nausea and vomitting grade 1-2, none had grade 3-4. Alopecia was seen in all patients. No renal or cardiac toxicity was found. Neurotoxicity such as peripheral neuropathy was not well recorded, but were seen in some patients, none of them had grade 3 or 4 . Serious side effects, namely grade 3 thrombocytopenia were seen in 5 patients (26\%), 1 patient (5\%) and 2 patients (11\%), respectively (Table 3).
Table 3. Side Effects of Paclitaxel \& Carboplatin Combination

\begin{tabular}{lcc}
\hline \multirow{2}{*}{ Toxicity Parameter } & \multicolumn{2}{c}{ WHO Grade (\%) } \\
\cline { 2 - 3 } & \multicolumn{2}{c}{3} \\
\hline Neutropenia & $5(31.3 \%)$ & I (6.3 \%) \\
Thrombocytopenia & $2(12.5 \%)$ & \\
Nausea/vomiting & & \\
Neurotoxicity & & \\
R'e n a l & \\
Cardiac & \\
\hline
\end{tabular}

\section{DISCUSSION}

Paclitaxel and carboplatin combination has been studied by many investigators with various results, as seen in Table 4 and 5. Using similar dose of paclitaxel and carboplatin, Johnson et al, Giaccone et al and Bunn et $\mathrm{al}^{4}$ had seen response rates of less than 50\% or more. Other investigators like Belani et al, Schutte et al, and Rowinsky et $\mathrm{al}^{4}$ used combinations of paclitaxel with carboplatin dosed to different targeted AUC-s, also had PR of over 50\%. Our result which was surprisingly high, may be due to more selected patients; as this is a retrospective report of patients after completing the treatment and follow up.

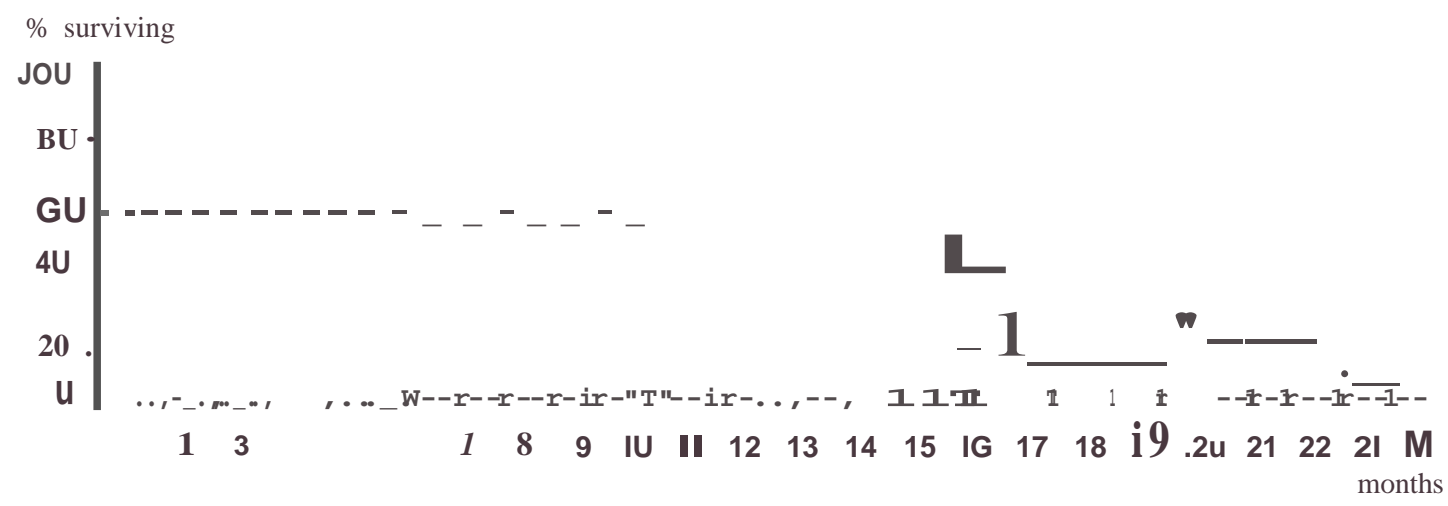

Figure 2. The Survival Curve of Patients with Stage JV Lung Cancer Receiving a Combination of Paclitaxel and Carhop/ $t$. Calculated after the Beginning of Chemotherapy $(n=14)$ 
table 6 reviews the side effects seen in our serie and in other studies. Neutropenia grade 3 and grade 4 seen in 10\% - 70\% cases, depending on the doses of drugs and that of the other modality. Thrombocytopenia grade 3 was found in $11 \%-20 \%$ of patients, none had grade IV trombocytopenia. Other side effects like gastrointestinal symptoms, myalgia, neurotoxicity, fatigue, renal toxicity, cardiac toxicity, hipersensitivity and other symptom/signs were seen, but otherwise quite tolerable to the patient.

Table 6. Side Effects of Paclitaxel and Carboplatin Combination in Various Regimens. Including Multimodality

$\begin{array}{lccccc}\begin{array}{c}\text { Side Effects } \\ \text { (grade } 3 \& 4 \text { ) }\end{array} & \text { Jusuf et al } & \text { Hainsowarth et al } & \text { Schute et al } & \text { Langer et al } & \text { Belani et } \\ & & & & & \\ \text { Neutropenia } & 37 \% & 10 \% & 16 \% & 70 \% & 22 \% \\ \text { Neutropenia + fever } & \text { NR } & 14 \% & \text { NR } & 2 \% & (-) \\ \text { Thrombopenia } & 11 \% & & & 20 \% & 6 \% \\ \text { Nausea \& vomitting } & & & & & 3 \%\end{array}$

Esophagitis \&

NR $\quad 48 \%$

- Myalgia

- Neurotoxicity

NR

- Renal toxicity

- Cardiac toxicity

- Hypersensitivity

- Death

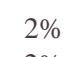

$2 \%$

$9 \%$

- Dose of Drugs \&

P. 135,175 , $200 \mathrm{mg} / \mathrm{m} 2$

P. $225 \mathrm{mg} / \mathrm{m} 2$

(I h)

P. $200 \mathrm{mg} / \mathrm{m} 2$

C. $200 \mathrm{mg} / \mathrm{m} 2$

C. AUC 7.5

C. AUC 5
P. $175 \mathrm{mg} / \mathrm{m} 2-$ $280 \mathrm{mg} / \mathrm{m} 2$
C. AUC 7.5
Prior radio- therapy in

P. $45 \mathrm{mg} / \mathrm{m} 2$

C. JOO $\mathrm{mg} / \mathrm{m} 2$ or AUC 6

\section{CONCLUSION}

1. Pacli taxel in combination with Carbopl atin is quite effective for stage III \& IV nonsrnall cell lu ng cancer, with 63\% response ra te (PR), one year survival rate of $58 \%$ and median survival time 14.2 months.

2. Major side effects are gastrointestinal symptoms (nausea and vomiting), alopecia and bone marrow depression, which are quite tolerable.

\section{Acknowledgement}

The authors wish to thank the Oncology Team, Bristol Meyer Squibb Indonesia for their support in carrying out this study and Dri1. Sita Lak.srni Andarini and Wahyu An i widyani ngsih, Miss Anggriani, SKM and Mr. Apong Sulaiman for preparing the report.

\section{REFERENCES}

I . Hainsworth JD. Thomson DS. Urba WJ. et al. One Hour Pacli taxel pl u s Carboplati n in Advanced Nonsmall Cell Lung Cancer (NSCLC). Preliminary Results of a Multiinstitution al Phase II Study, Scientific Proceedings, $32^{00}$ An nual Meeti ng, American Thoracic Society of Clinical Oncology, $1996: 125$.

2. Langer C. Kaplan R. Rosvold E. et al. Paclitaxel (P) by I hr Infusion Combination with Carboplatin (C) in Ad vanced Nonsmall Cell Lung Carcinoma (NSCLC) : A Phase II Study J. Clin Oncology 1995, 13: 1860-70.

3. Schutte W. Bork I. Sucker S. Phase II Trial of Paclitaxel and Carboplatin as First Line Treatment in Advanced Nonsmall Cell Lung Cancer, Scientific Proceedings, 32n<l Annual Meeting, American Thoracic Society of Clinical Oncology, 1996 : 137.

4. Belani CP. Paclitaxel/Carboplatin in the Treatment of Nonsmall Cell Lung Cancer. Oncology (Suppl), 1998, 12 : 74-9.

5. Pisters KMW, Ginsberg RJ. Phase II Trial of Induction Pacl itaxel \& Carboplatin (PC) in Early Stage (T2NO, TI -2 N I \& Selected T3NO-I), Nonsmall Cell Carcinoma, 
Scientific Proceedings, 34th Annual Meeting, American Thoracic Society, 1998:129.

6. Langer C. Kaplan R. Rosvold E. Milleson M. Smith MR. Johnson C, et al. Paclitaxel (P) by $1 \mathrm{hr}$ Infusion Combination with Carboplatin (C) in Advanced Nonsmall Cell Lung Carcinoma (NSCLC) : A Phase II Study, Scientific Proceedings, 32nd Annual Meeting, American Thoracic Society of Clinical Oncology, 1996:135.
7. N, Triaspolitica. "Yang Perlu Anda Ketahui Tentang Penyakit Kanker Paru Paru, Gejala Umum, Penyebab, Serta Pengobatan." Mau Nanya Dong Dok. N.p, 29 June 2017. Web. $29 \quad$ June $2017 . \quad<$ https:// nanyadongdok.blogspot.com/2017/06/yang-perlu-andaketahui-tentang.html>. 